MARIO NOVAK,

Anthropological Centre, Croatian Academy of

Sciences and Arts,

Zagreb, Croatia

mnovak@hazu.hr
UDC: 902:572(497.5)

Original research article

Received: March $5^{\text {th }} 2013$

Accepted: October $15^{\text {th }} 2013$

\title{
THE ROLE OF BIOARCHAEOLOGY IN PRESENTATION AND POPULARISATION OF SCIENCE IN CROATIA
}

\begin{abstract}
The paper briefly presents the historical development and current status of bioarchaeological research in Croatia. Special emphasis is placed on activities that are performed continuously over the past twenty years with the purpose of promotion and presentation of bioarchaeology as a science among professionals (archaeologists) and in general public, especially among younger audience. The promotion of bioarchaeology among archaeologists includes joint publications of scientific articles between archaeologists and bioarcheologists, bioarchaeological lectures at professional meetings and joint organization of exhibitions and book presentations. In general public these activities consist of public lectures in schools and faculties, organisation of bioarchaeological workshops, organised visits to the bioarchaeological labs, and numerous appearances of bioarchaeologists in mass media (newspapers, television, radio, Internet). All of these activities have led to a significant change in the perception of bioarchaeology, both among archaeologists and in general public, and today in Croatia all archaeological excavations of human skeletal remains result in bioarchaeological studies of the recovered material, while frequent appearances in media, combined with public lectures and presentations, have made bioarchaeology one of the most popular scientific branches with a very positive response in general public.
\end{abstract}

Keywords: bioarchaeology, Croatia, science, presentation, lectures, mass media, workshops.

\section{INTRODUCTION}

Bioarchaeology is a science that studies human skeletal and dental remains from archaeological context; it also reconstructs living conditions and quality of life of archaeological populations. Bioarchaeology serves as a supplement to the ar- chaeological and historical data, but it also reveals important information that can not be obtained by the archaeological excavations and historical studies. The term was first used by a British archaeologist G. Clark (1972) in order to define the study and analysis of animal bones found during archaeological excavations. In 1977 American archaeologist 
J. Buikstra (1977) provided a new definition of bioarchaeology which is still used - a study of human skeletal remains found during archaeological excavations. Today, terms such as osteoarchaeology, skeletal biology or palaeoosteology are sometimes used instead of the term bioarchaeology. Biological anthropology during the 19th and the first half of the 20th century was reduced to descriptive, mostly anatomically oriented descriptions of human skeletal remains or recognised pathological conditions that sometimes supplemented archaeological publications. During the 60 's of the last century analytical methods and theories that enabled a new approach to the study of human osteological remains started to develop, and the major difference was in the shift from the typological way of thinking toward the orientation based on the idea of studying the interaction processes between human biological and socio-cultural phenomena, and the study of biological structures (e.g. Baker 1966; Johnston 1966).

This new approach has led to the fact that human bones were analysed in the context of human interaction with its environment and ecological system that surrounds it. This development was prompted by several factors. The first factor was the development of multivariate statistical methods and their use in bioarchaeological analyses (e.g. Jantz 1973; Rösing and Schwidetzky 1977), significantly facilitated by the increased availability of personal computers that allowed quick and easy application of these analyses. Another factor was the shift in focus of anthropological analyses from the descriptive characterisation of one individual toward the entire population that became the main object of study. Furthermore, reliable and standard methods for determination of sex (e.g. Giles and Elliot 1963; Phenice 1969) and age at death (e.g. Fazekas and Kósa 1978; Gilbert and McKern 1973) on human skeletal material were developed and generally accepted. Finally, large, precisely dated and thoroughly documented archaeological collections of skeletal material have become available for bioarchaeological studies.

\section{SHORT HISTORY OF BIOARCHAEOLOGY IN CROATIA}

The beginnings of bioarchaeological research in Croatia are related to the paleoanthropological studies carried out by D. Gorjanović-Kramberger at the end of 19th and the beginning of the 20th century (Gorjanović-Kramberger 1899, 1906). His analysis of the Neanderthal skeletal material recovered from Hušnjakovo brdo near Krapina significantly contributed to the acceptance of the existence of fossil man, and thus, to the acceptance of the concept of the evolution of mankind (Šlaus et al. 2011). Bioarchaeological analyses of modern man in Croatia began after the Second World War with two major publications by F. Ivaniček. In these works he presented the results of detailed paleodemographic and craniometric analyses of the medieval sites of Bijelo Brdo (Ivaniček 1949) and Ptuj (Ivaniček 1951). Two decades later G. Pilarić published several papers that focused on the craniometric characteristics of Early Mediaeval Croat populations (Pilarić 1967, 1968). During the 80's Serbian anthropologist Ž. Mikić also published results of the anthropological analysis of several Croatian mediaeval populations (Mikić 1983, 1990).

During this period a major leap forward in Croatian physical anthropology and bioarchaeology began mostly due the founding of the Croatian Anthropological Society and the scientific journal Collegium Antropologicum in 1977 by H. Maver and P. Rudan. They organised numerous international scientific workshops such as the annually held School of Biological Anthropology that led to the founding of the first scientific and educational institution dedicated exclusively to anthropological research in Croatia - the Institute of Anthropology in Zagreb established in 1992.

\section{BIOARCHAEOLOGY IN CROATIA TODAY}

Modern bioarchaeological studies, equal to those carried out in Europe and the United States, began in Croatia during the early 90's of the last century. Today, bioarchaeological and physical anthropological analyses are performed in numerous Croatian scientific centres of excellence such as the Institute of Anthropology (I. Janković, Z. Premužić, P. Rajić Šikanjić), the Department of Archaeology at the Faculty of Humanities and Social Sciences in Zagreb (Z. Hincak), the Institute for Archaeology in Zagreb (J. Boljunčić), the University Centre for Forensic Sciences in Split ( $\breve{S}$. Anđelinović, I. Anterić, Ž. Bašić), the Department of Dental Anthropology at the School of Dental Medicine in Zagreb (H. Brkić, M. Vodanović), and the Anthropological Centre of the Croatian Academy of Sciences and 
Arts (Ž. Bedić, M. Novak, M. Šlaus, V. Vyroubal). The results of these studies are published in monographs and in the domestic and international peer-reviewed journals of the highest quality ${ }^{1}$.

The leading centre for bioarchaeological research in Croatia today is the Anthropological Centre of the Croatian Academy of Sciences and Arts in Zagreb where several scientists are actively engaged in bioarchaeological studies of archaeological populations from the territory of Croatia, but also from the neighbouring countries. They study a wide range of topics including demography, subadult stress, infectious diseases, dental pathologies, bone trauma, vertebral pathologies, etc. Biorchaeologists from the Anthropological Centre corroborate with numerous scientists from Croatia and abroad covering a wide range of scientific disciplines such as archaeology, history, molecular genetics, radiology, dentistry, etc. The osteological collection of the Anthropological Centre of the Croatian Academy, established in 1991, is the largest collection of human skeletal material in Croatia - it holds skeletal material from numerous archaeological sites in Croatia dating from the Mesolithic period to the 19th century AD with a total number of over 5000 skeletons.

In addition to scientific work, Croatian bioarchaeologists participate in educational activities as lecturers at several universities in Croatia. The courses in bioarchaeology are taught at the Department of Archaeology at the University in Zadar and the Department of Archaeology at the Faculty of Humanities and Social Sciences in Zagreb, while courses in Forensic Anthropology, which include topics in bioarchaeology, are taught at the Chair of Anthropology at the Faculty of Humanities and Social Sciences in Zagreb and the University Centre for Forensic Sciences in Split.

\section{PRESENTATION AND POPULARISATION OF BIOARCHAEOLOGY IN CROATIA}

Efforts in presentation and popularisation of bioarchaeology in Croatia have been carried out continuously for the last 20 years. These actions are conducted simultaneously on two fronts - among professionals (archaeologists) and in general public.

1 For a complete list of publications published up until year 2011 see Šlaus et al. (2011).
The efforts in popularisation of bioarchaeology among the professional public (archaeologists) mostly include joint publications of scientific articles/books between archaeologists and bioarchaeologists (Fig. 1) and lectures with topics in bioarchaeology at professional meetings such as the annual scientific meetings of the Croatian Archaeological Society. Today, as a result of these actions bioarchaeological articles are published in all major Croatian archaeological journals as well as in numerous international archaeological/ anthropological/medical journals. Also, several books in Croatian and English languages dealing with bioarchaeological studies were published recently gaining considerable attention and positive feedback from archaeologists, but also from the mass media. All the mentioned efforts resulted in the increased interest of archaeologists for the preservation and analysis of human skeletal material. The vast majority of Croatian archaeologists today are aware of the usefulness of bioarchaeological analyses for reconstructing the quality of life of past populations, and the result is that virtually all human bones found in archaeological sites in Croatia today are analysed (Šlaus et al. 2011).

A special category of lectures with bioarchaeological topics are those held as part of the presentations of archaeological monographs and during the openings of archaeological exhibitions. A close collaboration of archaeologists and bioarchaeologists is of key importance in organising such events, and in this context it is necessary to mention two archaeological institutions from Croatia that understood the importance of such an approach and the mutual cooperation in the promotion of science - the Institute of Archaeology from Zagreb and the Archaeological Museum Zadar. Bioarchaeologists from the Anthropological Centre of the Croatian Academy closely corroborate with archaeologists from these two institutions for more than a decade in the preparation of exhibitions and lectures, as well as in media appearances such as the press conference on the occasion of discovery and opening of the Early Mediaeval sarcophagus of monk Juraj in Zadar in the spring of 2011.

Very important are the actions carried out in presentation and popularisation of bioarchaeology among general audience, especially among the school children and students. Presentation 


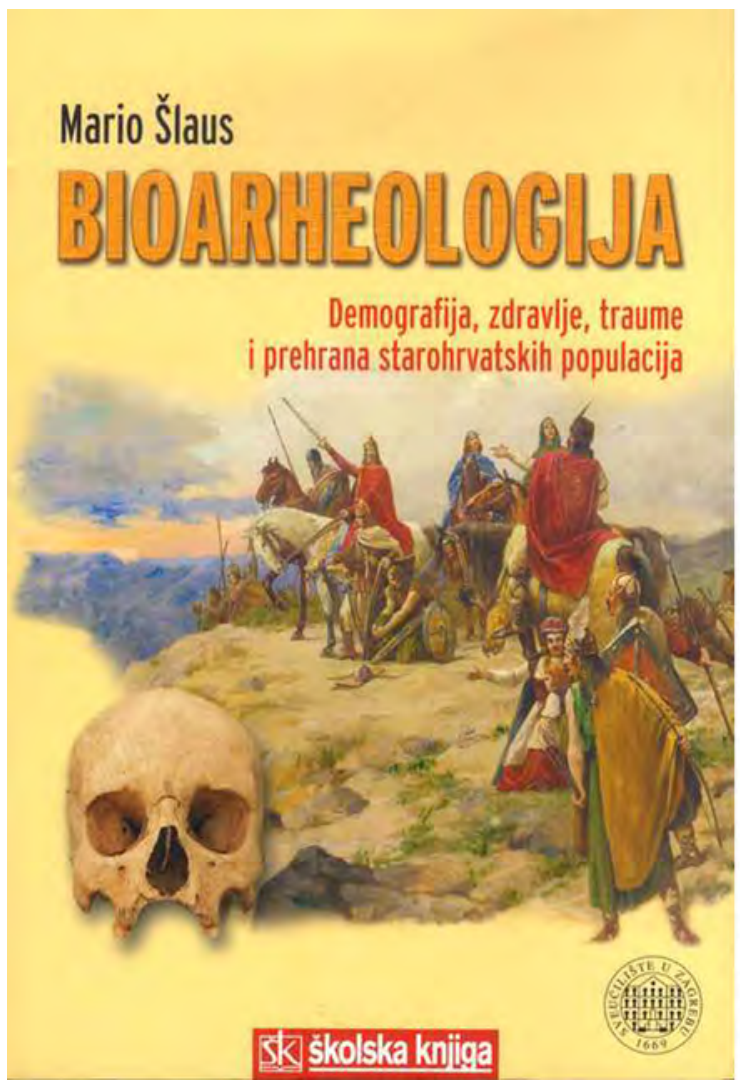

Petra Rajić Šikanjić

\section{Priručnik za iskopavanje, rukovanje i analizu ljudskih skeletnih ostataka iz arheološkoga konteksta}

Fig. 1 Books with bioarchaeological topics published in Croatia in the last few years.

of bioarchaeology in this target group is primarily done through lectures in high schools and/ or universities, through organised arrival of students to the osteological laboratory where they are introduced with methods and techniques used in the bioarchaeological analyses, and through public lectures held during various science manifestations. Very important for the promotion of bioarchaeology among students is the already mentioned School of Biological Anthropology organised by the Institute of Anthropology in Zagreb, held annually, with lecturers who are the world's biggest experts in the field of biological anthropology. In this context one should not ignore the event launched in 2011 named Croatian Academy Open Door Days, also taking place once a year, during which two highly attended bioarchaeological workshops with lectures were held (Fig. 2), with a vast majority of younger visitors.

The mass media played the most important role in the promotion and presentation of bioarchaeology to the general public in Croatia, in addition to workshops, lectures and exhibitions. It may be safely said that the mass media in Croatia recognised bioarchaeology as a very attractive branch of science in which humanities and natural sciences are combined, and that the mass media played a crucial role in creating a positive opinion toward the bioarchaeology in the general public.

Bioarchaeological topics in Croatia today can be found in all major daily and weekly newspapers (Večernji list, Jutarnji list, 24 sata, Globus, etc.) (Fig. 3). Except in the newspapers, bioarchaeological topics are also systematically covered by numerous Internet news portals. But, probably the most important role in the affirmation of bioarchaeology in Croatia had the state-owned Croatian Television and Croatian Radio. In the last decade, as a part of its scientific, educational and informational programs, Croatian Television broadcasted many reports describing the work of bioarchaeologists in the laboratory and during excavations, while numerous bioarchaeologists gave interviews in which they presented their work; on several occasions TV documentaries (Scientia Croatica, It is good to know, Scientific Five, Moment of Truth, etc.) dealing with specific bioarchaeological topics with the participation of 


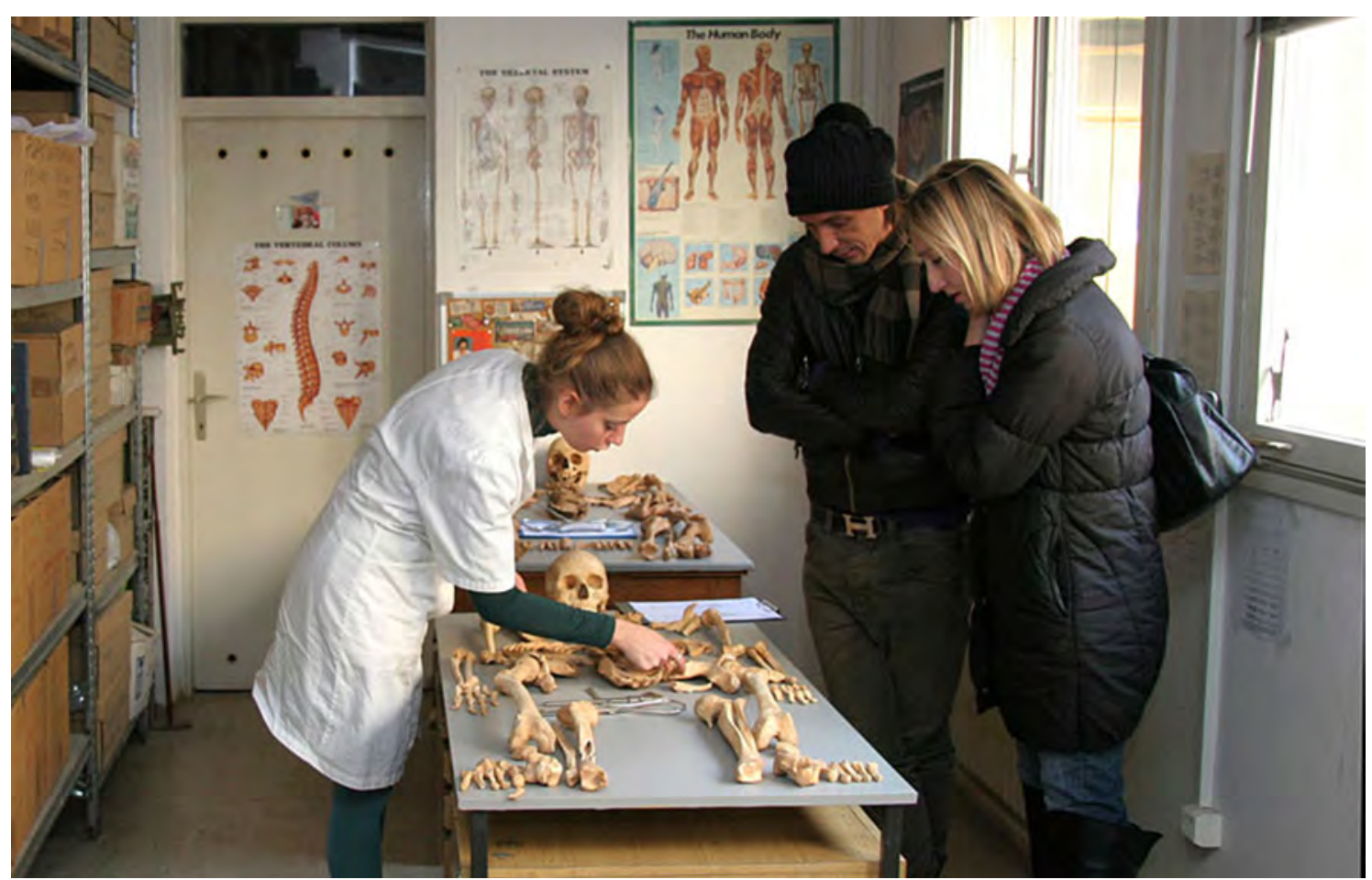

Fig. 2 Bioarchaeological workshop held during the Croatian Academy Open Door Days in November 2011.

leading Croatian bioarchaeologists were shown. Croatian Radio also intensively covers such topics - as an example, bioarchaeologists from the Anthropological Centre of the Croatian Academy appeared twice on the show titled Wonderful New World during December 2012. As for the commercial television and radio stations, they also continuously monitor the work of Croatian bioarchaeologists, but mostly through informational programs.

Along with all the facts mentioned above, it should be noted that the shooting of a documentary drama titled Written in Bones has just been finished. It was filmed by the Croatian Television with participation of the bioarchaeologists from the Anthropological Centre of the Croatian Academy along with numerous experts from other scientific fields such as historians, archaeologists, physicians, molecular biologists from Croatia and abroad. The show consists of five episodes, with each episode covering certain aspects presented through bioarchaeological studies of human skeletal remains from the Croatian archaeological sites dated from the Early Neolithic to the Late Middle Ages. In a popular, but scientifically accurate manner the show will try to reconstruct the living conditions of past populations, which should contribute to further acceptance and pop- ularisation of bioarchaeology as a science among wider audience in Croatia.

All actions comprehensively described in this chapter led to a significant change of attitude toward bioarchaeology in Croatia during the last two decades. Twenty years ago most archaeologists in Croatia regarded human bones as redundant material that just backfilled museum storerooms and from which one could not obtain new and useful data, so most of the skeletal material from archaeological context was re-buried in unmarked mass graves without any labels or even burned on huge pyres. Today, all archaeological excavations of human skeletal remains in Croatia result in bioarchaeological studies and publication of the obtained results due to the multidisciplinary approach and intense cooperation between field archaeologists and bioarchaeologists. The similar attitude also prevailed among the general public - most people saw bioarchaeology as an unnecessary scientific branch on which taxpayer's money was wasted. But, as a result of frequent appearances in mass media, combined with public lectures and presentations, today bioarchaeology is one of the most popular scientific branches in Croatia with extremely positive response in general public. Of course, numerous forensic 


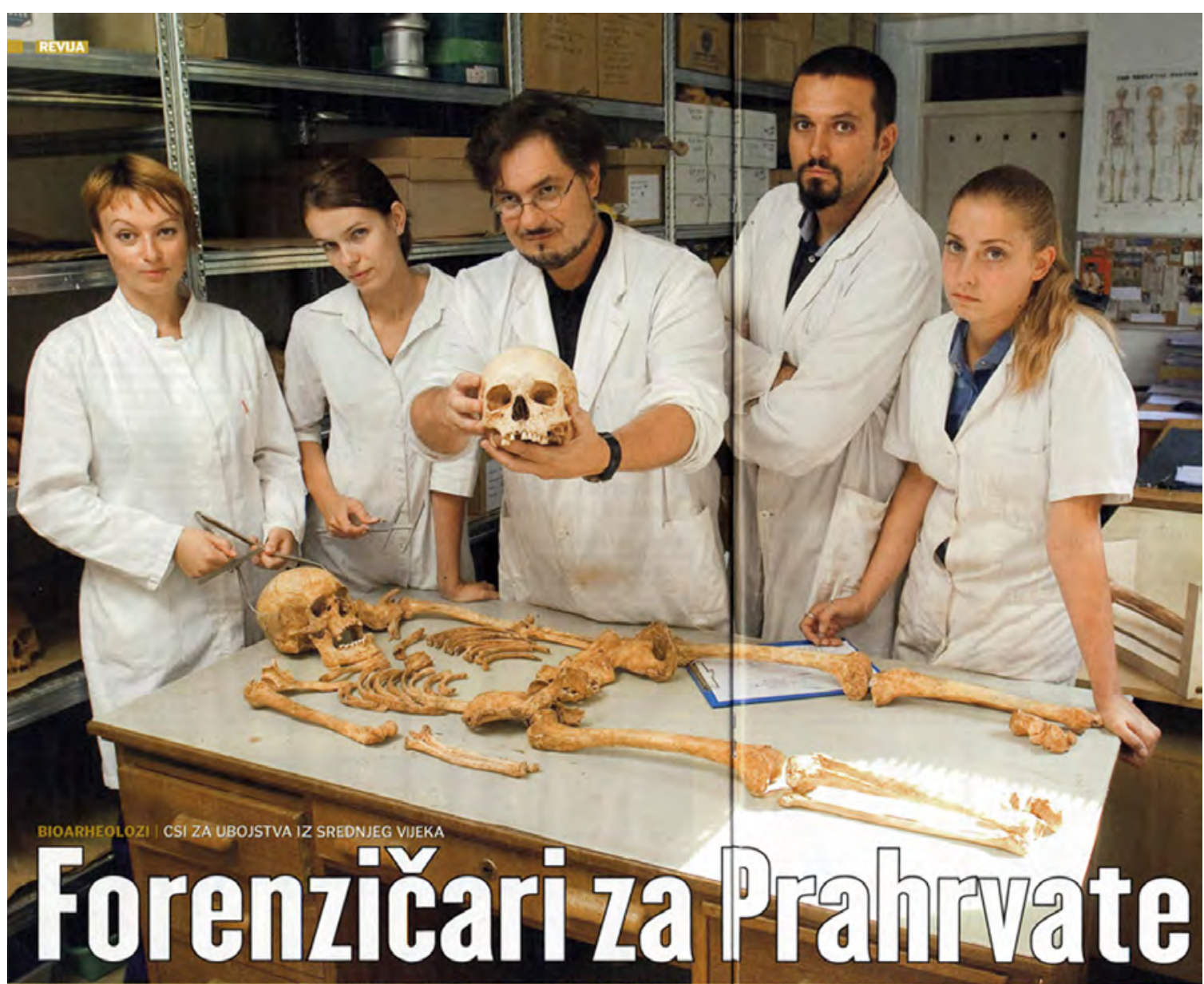

Stari Hrvati bili su snažni i tukli su se više nego neandertalci, ali nilada nisu fizički zlostavljali ni žene niti djecu

Fig. 3 Article from the weekly magazine Globus describing the work of bioarchaeological team from the Anthropological Centre of the Croatian Academy.

TV shows broadcasted on several TV stations also helped to change this attitude so bioarchaeological teams are sometimes referred to as "CSI bioarchaeology team Croatia” in the mass media.

\section{FUTURE PLANS}

Although it can be said that the bioarchaeology in Croatia today is very popular with a positive feedback among both professionals and general audience the additional efforts are necessary in order to make this scientific branch even more attractive. These actions should be concentrated into two directions. The first includes stronger cooperation between Croatian bioarchaeologists and those from the wider region, i.e. work on mutual scientific projects, creation of large osteological databases that will not be limited by contemporary boundaries, and organisation of joint scien- tific meetings. The second one is more oriented toward the general public and is mostly based on the multimedia approach - it consists of informing the public, especially younger audience, about bioarchaeology and its goals through new media such as Facebook and Twitter as well as the creation of large online bioarchaeological databases that will be available to all interested parties.

\section{BIBLIOGRAPHY}

\section{Baker, P.T. 1966}

Human biological variation as an adaptive response to the environment, Eugenics Quarterly 13(2): 81-91.

\section{Buikstra, J.E. 1977}

Biocultural dimensions of archaeological study: a regional perspective, in: Biocultural Adaptation in Prehistoric America, R.L. Blakely, (ed.), Ath- 
ens: University of Georgia: 67-84.

Clark, G. 1972

Star Carr: a case study in Bioarchaeology, Boston: Addison Wesley modular publications.

\section{Fazekas, I.G., and Kósa, F 1978}

Forensic fetal osteology, Budapest: Akadémiai Kiadó.

\section{Gilbert, B.M., and McKern, T.W. 1973}

A method for aging the female os pubis, American Journal of Physical Anthropology 38(1): 31-38.

\section{Giles, E., and Elliot, O. 1963}

Sex determination by discriminant function analysis of the crania, American Journal of Physical Anthropology 21(1): 53-68.

\section{Gorjanović-Kramberger, D. 1899}

Paleolitički ostaci čovjeka i njegovih suvremenika iz diluvija u Krapini, Ljetopis Jugoslavenske akademije znanosti i umjetnosti 14: 90-98.

\section{Gorjanović-Kramberger, D. 1906}

Der diluviale Mensch von Krapina in Kroatien. Ein Beitrag zur Paläoanthropologie, Wiesbaden: Kriedel.

\section{Ivaniček, F. 1949}

Istraživanje nekropole ranog srednjeg vijeka u Bijelom Brdu, Ljetopis Jugoslavenske akademije znanosti i umjetnosti 55: 111-144.

\section{Ivaniček, F. 1951}

Staroslavenska nekropola u Ptuju - rezultati antropoloških istraživanja, Ljubljana: Slovenska akademija znanosti in umetnosti.

\section{Jantz, R.L. 1973}

Microevolutionary change in Arikara crania: A multivariate analysis, American Journal of Physical Anthropology 38(1): 15-26.

\section{Johnston, F. E. 1966}

The population approach to human variation, Annals of the New York Academy of Sciences 134: 507-515.

\section{Mikić, Ž. 1983}

Antropološki prikaz srednjovekovnih stanovnika Ričica, in: J. Jeličić, (ed.), Ričice - nekropole stećaka, Split: Regionalni zavod za zaštitu spomenika kulture, 45-59.

\section{Mikić, Ž. 1990}

Antropološki profil srednjovekovne nekropole u Mravincima kod Splita, Vjesnik za arheologiju $i$ historiju dalmatinsku 83: 225-232.

\section{Phenice, T.W. 1969}

A newly developed visual method of sexing the os pubis, American Journal of Physical Anthropology 30(2): 297-301.

\section{Pilarić, G. 1967}

Antropološka istraživanja starohrvatskog groblja u Daraž-Bošnjacima 1961. godine, Arheološki radovi i rasprave 4/5: 419-443.

\section{Pilarić, G. 1968}

Fenotipske značajke bjelobrdskih lubanja iz ranog srednjeg vijeka, Arheološki radovi i rasprave 6: 263-291.

\section{Rösing, F.-W., and Schwidetzky, I. 1977}

Vergleichend-statistische Untersuchungen zur Anthropologie des frühen Mittelalters (500-1000 n.d.Z.), Homo 28: 65-116.

Šlaus, M., Novak, M., and Vodanović, M. 2011 Croatia, in: N. Marquez Grant, L. Fibiger (eds.), The Routledge Handbook of Archaeological Human Remains and Legislation: An International Guide to Laws and Practice in the Excavation and Treatment of Archaeological Human Remains, Routledge: London: 83-96. 
REZIME

\section{ULOGA BIOARHEOLOGIJE U PROMOCIJI I POPULARIZACIJI NAUKE U HRVATSKOJ}

Ključne reči: bioarheologija, Hrvatska, nauka, prezentacija, predavanja, mediji, radionice.

Rad ukratko prikazuje istorijski razvoj i trenutni status bioarheoloških istraživanja u Hrvatskoj. Poseban akcenat je stavljen na aktivnosti koje se obavljaju u kontinuitetu u poslednjih dvadeset godina u promociji i prezentaciji bioarheologije kao nauke među profesionalcima (arheolozima) i u široj javnosti, posebno među mlađom publikom. Promocija bioarhaeologije među arheolozima obuhvata zajedničke publikacije naučnih članaka između arheologa i bioarheologa, bioarheološka predavanja na stručnim skupovima i zajedničko organizovanje izložbi i prezentacije knjiga. U najširoj javnosti ove aktivnosti se sastoje od javnih predavanja u školama i na fakultetima, organizovanja bioarheoloških radionica, organizovanih poseta bioarheološkim laboratorijama, kao i brojnih nastupa bioarheologa u javnim medijima (novine, televizija, radio, internet). Sve ove aktivnosti dovele su do značajne promene u percepciji bioarheologije, među arheolozima i u široj javnosti, pa danas u Hrvatskoj sva arheološka iskopavanja ljudskih skeletnih ostataka rezultuju bioarheološkim studijama pronađenog materijala, dok su česte pojave u medijima, u kombinaciji sa javnim predavanjima i prezentacijama, učinili bioarheologiju jednom od najpopularnijih naučnih grana, sa veoma pozitivnim stavom u javnosti. 